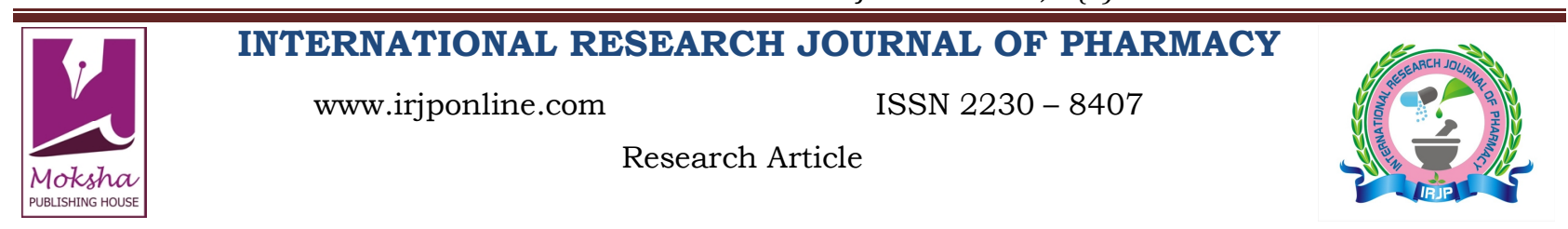

\title{
FORMULATION DEVELOPMENT AND EVALUATION OF IMMEDIATE RELEASE BILAYER TABLETS OF TELMISERTAN AND HYDROCHLOROTHIAZIDE
}

Bhavsar Bhavesh $^{1 *}$, Chauhan Manish ${ }^{2}$, Biswal Biswajit ${ }^{3}$

${ }^{1}$ Faculty of Pharmacy, CMJ University, Shillong, India

${ }^{2}$ Group Leader, Astron Research Limited, Ahmadabad, India

${ }^{3}$ Assistant Professor, B. Pharmacy College Rampura - Kakanpur, Gujarat, India

*Corresponding Author Email: bhaveshbhavsar76@gmail.com

Article Received on: 16/08/13 Revised on: 01/09/13 Approved for publication: 05/09/13

DOI: 10.7897/2230-8407.04925

IRJP is an official publication of Moksha Publishing House. Website: www.mokshaph.com

(C) All rights reserved.

\section{ABSTRACT}

A low-dose combination of two different agents reduces the dose related risk; the addition of one agent may counter act some deleterious effects of the other. Using low dosage of two different agents minimizes the clinical and metabolic effects that occur with maximal dosage of individual component of the combined tablet and thus dosage of the single component can be reduced. The primary objective of formulation development was to develop a stable, essentially similar, robust and bioequivalent formulation of Telmisartan and HCTZ combination for synergistic effect which complies with the Reference product.

Keywords: Immediate release tablet, immediate release bilayer tablet, Telmisartan, HCTZ, Dissolution in $7.5 \mathrm{pH}$ buffer.

\section{INTRODUCTION}

The developments of enhanced oral protein delivery technology by immediate release tablets which may release the drugs at an enhanced rate are very promising for the delivery of poorly soluble drugs high molecular weight protein and peptide. The oral route remains the perfect route for the administration of therapeutic agents because the low cost of therapy, manufacturing and ease of administration lead to high levels of patient compliance ${ }^{1}$. The concept of immediate release tablets emerged from the desire to provide patient with more conventional means of taking their medication when emergency treatment is required. Immediate release solid oral dosage forms are classified as either having rapid or slow dissolution rates. Immediate release dosage forms are those for which $\geq 85 \%$ of labeled amount dissolves within 30 minutes $^{2.3}$.

\section{Fixed Dose Combination}

The goal of antihypertensive therapy is to abolish the risks associated with blood pressure (BP) elevation without adversely affecting quality of life. Epidemiologic studies and clinical trials have been used to define individual risk and set appropriate BP targets, recognizing that these targets reflect expert consensus based on available data and are subject to revision as additional evidence is obtained ${ }^{4,6}$. Drug selection is based on efficacy in lowering $\mathrm{BP}$ and in reducing cardiovascular $(\mathrm{CV})$ end points including stroke, myocardial infarction, and heart failure. As a result, there has been a progressive lowering of BP targets in large segments of the hypertensive population, including diabetics and patients with established renal or vascular disease ${ }^{7,8}$.

\section{MATERIAL AND METHOD}

Telmisartan and Hydrochlorothiazide was obtain as a gift sample from MSN Pharmachem Pvt. Ltd and CTX Life Sciences Pvt. Ltd. Mannitol 200 SD from Roquette Pharma, Sorbitol from Roquette Pharma, Avicel 102 from Signet Chemicals, Povidone K 30 from BASF Ltd, Magnesium stearate from Signet chemicals, Lactose Monohydrate from DMV Fonterra Excipients limited, Meglumine from Triveni
Chemicals, Sodium Stearyl Fumarate from Maruti Chemicals, Ferric Oxide Yellow from Triveni Chemicals, Sodium Hydroxide from Ghanshyam Chem. Industries.

\section{Methodology \\ Preparation of Tablets}

Trial with Single Layer Tablets

Aim

To take trial for Telmisartan single layer in RMG

\section{Rationale}

Telmisartan is practically insoluble in water and in the $\mathrm{pH}$ range of 3 to 9 and is soluble in strong base so Sodium Hydroxide solution is required to dissolve the drug and Meglumine was added to the solution to maintain micro environment $\mathrm{pH}$ of the drug solution. Povidone $\mathrm{K} 30$ was used as a binder and Magnesium Stearate was selected as lubricant and as a glidant also.

\section{Manufacturing Process \\ Shifting \\ Ingredient 1 was shifted through 40\# mesh.}

\section{Preparation of drug binder solution \\ Step 1}

Weight quantity of ingredient 4 and 5 were added to required quantity of water and stirred to obtain a clear solution.

\section{Step 2}

Weight quantity ingredient 3 was dissolved to required quantity of water and then the weight quantity of ingredient 2 was added. Required quantity of water was added to obtain clear solution.

Step 3

Mix both the solution of step 1 and step 2 and stir for 15 minutes.

\section{Granulation}

Granulate blend of shifted material using binder solution. 
Trial with Bilayer Tablets

Aim

To take trial for Telmisartan layer by using Fluidized Bed Processor and HCTZ layer by using RMG.

\section{Rationale}

By using Sorbitol as diluent, sticking on expansion chamber were observed. To overcome this problem isomer of sorbitol was used in this trial.

\section{Manufacturing Process}

\section{Shifting}

Ingredient 1 was shifted through $30 \#$ mesh.

\section{Preparation of drug spraying solution}

As per the trial 1

\section{Granulation}

Ingredient 1 was shifted to expansion chamber of Fluidized Bed Processor and other parameters were set.

\section{Drying}

Drying was done in same equipment till LOD of blend was less than $1.5 \%$

\section{Shifting}

The dried granules were shifted through $30 \#$ mesh manually.

\section{Lubrication}

Ingredient 7 was weighed and shifted through $40 \#$ mesh and mix with the dried shifted granules.

\section{Blending}

Blending was done in Octagonal blender for 10 minutes

\section{RESULT AND DISCUSSION}

\section{Trial 01 (Trial with Single Layer Tablets)}

Formation of lumps was observed because diluent quantity was insufficient to accommodate binder solution. So Lumps were discarded. In Next trial was planned with use of insoluble diluent to overcome lumps formation.

\section{Trial 02 (Trial with Single Layer Tablets)}

Blend turned to yellow colour due to the degradation of Microcrystalline Cellulose. So Lumps were discarded. In Next trial was planned with use of another approach of using Fluidized Bed Processor instead of Rapid Mixture Granulator for granulation.

\section{Trial 03 (Trial with Single Layer Tablets)}

Sorbitol sticking was observed on the walls of FBP expansion chamber. So To avoid sticking problem on expansion chamber, Sorbitol was replaced with Mannitol and Mannitol is an isomer of Sorbitol with high melting point and was used as diluents in next trial.

\section{Trial 04 (Trial with Bilayer Tablets)}

Compaction and compression parameters were satisfactory. The drug release profile of Telmisartan was very slow than innovator's drug release profile. The drug release profile of HCTZ was found to be satisfactory with the innovator's drug release profile. In next trial was planned to increase the release of Telmisartan layer so that three strategies in trial 5 were applied. Strategy 1 Binder quantity was reduced, Strategy 2 Have change lubricant, Strategy 3 Lubricant quantity was reduced

\section{Trial 05 (Trial with Bilayer Tablets)}

Compaction and compression parameters were satisfactory The drug release profile of Telmisartan was very slow than innovator's drug release profile. The drug release profile of HCTZ was found to be satisfactory with the innovator's drug release profile. In next strategy Magnesium Stearate was replaced with Sodium Stearyl Fumarate was planned to increase the release of Telmisartan layer and common granules of HCTZ of strategy 1 was used in this strategy.

\section{Trial 05 (B)}

Compaction and compression parameters were satisfactory. The drug release profile of Telmisartan was very fast than innovator's drug release profile. The drug release profile of HCTZ was found to be satisfactory with the innovator's drug release profile in previous strategy and in this strategy common granules were used therefore we did not go for dissolution study of HCTZ. In next strategy the amount of Magnesium Stearate was reduced to match the dissolution profile of Telmisartan with innovator`s profile.

\section{Trial $05(C)$}

Sticking was observed on turret of compression machine due to law amount of lubricant. After performing various strategies we reached to the following conclusions if we use Magnesium Stearate as lubricant then we observe slow dissolution than innovator profile. If we use Sodium Stearyl Fumarate as lubricant then we observe fast dissolution than innovator profile. If we use low amount of Magnesium Stearate then we observe sticking. So the next trial was planned by using both Magnesium Stearate and Sodium Stearyl Fumarate as lubricant in different ratio to match dissolution profile of Telmisartan with innovator's profile.

\section{Trial 06 (Trial with Bilayer Tablets)}

Compaction and compression parameters were satisfactory. The drug release profile of Telmisartan was found to be satisfactory with the innovator's drug release profile. The drug release profile of HCTZ was found to be satisfactory with the innovator's drug release profile in previous strategy and in this strategy common granules were used therefore we did not go for dissolution study of HCTZ. Though the dissolution of both drugs was met to the specification, we have tried another ratio of Magnesium Stearate and Sodium Stearyl Fumarate in next strategy to know the effect of lubricant on formulation.

Trial 06 (B) (Magnesium Stearate: Sodium Stearyl Fumarate is 50:50)

Compaction and compression parameters were satisfactory. The drug release profile of Telmisartan was fast in initial time point than innovator's drug release profile. The drug release profile of HCTZ was found to be satisfactory with the innovator's drug release profile in previous sub trial and in this trial common granules were used therefore we did not go for dissolution study of HCTZ. In next trial Magnesium Stearate and Sodium Stearyl Fumarate ratio was 25: 75. 
Bhavsar Bhavesh et al. Int. Res. J. Pharm. 2013, 4 (9)

Table 1: Compositions of Immediate Release Table (Single Layer with Telmisartan)

\begin{tabular}{|c|c|c|c|}
\hline \multirow{2}{*}{ Ingredients } & \multicolumn{3}{|c|}{ Quantity ( mg / Tablet ) } \\
\cline { 2 - 4 } & T-01 & T-02 & T-03 \\
\hline Sorbitol & 337.28 & --- & 337.28 \\
\hline Microcrystalline Cellulose & --- & 337.28 & --- \\
\hline \multicolumn{4}{|c|}{ Binder Solution } \\
\hline Telmisartan & 80.00 & 80.00 & 80.00 \\
\hline Sodium Hydroxide & 6.72 & 6.72 & 6.72 \\
\hline Meglumine & 24.00 & 24.00 & 24.00 \\
\hline Povidone K30 & 24.00 & 24.00 & 24.00 \\
\hline Water & Q.S. & Q.S. & Q.S. \\
\hline \multicolumn{4}{|c|}{ Lubrication } \\
\hline Magnesium Stearate & 8.00 & 8.00 & 8.00 \\
\hline Total ( mg / Tablet ) & $\mathbf{4 8 0 . 0 0}$ & $\mathbf{4 8 0 . 0 0}$ & $\mathbf{4 8 0 . 0 0}$ \\
\hline
\end{tabular}

Table 2: Trial with Bilayer Tablets (Telmisartan and HCTZ)

\begin{tabular}{|c|c|c|c|c|c|c|}
\hline \multirow[t]{2}{*}{ Ingredients } & \multicolumn{6}{|c|}{ Quantity ( mg / Tablet ) } \\
\hline & T-05 A & T-05 B & T- $05 \mathrm{C}$ & T- 06 A & T- 06 B & T- 06 C \\
\hline Mannitol & 347.28 & 347.28 & 347.28 & 337.28 & 337.28 & 337.28 \\
\hline \multicolumn{7}{|c|}{ Binder Solution } \\
\hline Telmisartan & 80.00 & 80.00 & 80.00 & 80.00 & 80.00 & 80.00 \\
\hline Sodium Hydroxide & 6.72 & 6.72 & 6.72 & 6.72 & 6.72 & 6.72 \\
\hline Meglumine & 24.00 & 24.00 & 24.00 & 24.00 & 24.00 & 24.00 \\
\hline Povidone K30 & 14.00 & 14.00 & 14.00 & 24.00 & 24.00 & 24.00 \\
\hline Water & Q.S. & Q.S. & Q.S. & Q.S. & Q.S. & Q.S. \\
\hline \multicolumn{7}{|c|}{ Lubrication } \\
\hline Magnesium Stearate & 8.00 & - & 4.00 & 6.00 & 4.00 & 2.00 \\
\hline Sodium Stearyl Fumarate & - & 8.00 & - & 2.00 & 4.00 & 6.00 \\
\hline Total & 480.00 & 480.00 & 476.00 & 480.00 & 480.00 & 480.00 \\
\hline HCTZ & 25.00 & 25.00 & 25.00 & 25.00 & 25.00 & 25.00 \\
\hline Lactose Monohydrate & 171.70 & 171.70 & 171.70 & 171.70 & 171.70 & 171.70 \\
\hline Ferric Oxide Yellow & 0.30 & 0.30 & 0.30 & 0.30 & 0.30 & 0.30 \\
\hline \multicolumn{7}{|c|}{ Binder Solution } \\
\hline Povidone K30 & 2.00 & 2.00 & 2.00 & 2.00 & 2.00 & 2.00 \\
\hline Water & Q.S. & Q.S. & Q.S. & Q.S. & Q.S. & Q.S. \\
\hline \multicolumn{7}{|c|}{ Lubrication } \\
\hline Magnesium Stearate & 1.00 & 1.00 & 1.00 & 1.00 & 1.00 & 1.00 \\
\hline Total & 200.00 & 200.00 & 200.00 & 200.00 & 200.00 & 200.00 \\
\hline
\end{tabular}

Table 3a: Granulation Parameter

\begin{tabular}{|c|c|c|c|c|c|c|c|}
\hline Time (min) & Inlet Temp. $\left({ }^{\circ} \mathrm{C}\right)$ & Outlet Temp. $\left({ }^{\circ} \mathrm{C}\right)$ & Bed Temp. $\left({ }^{\circ} \mathrm{C}\right)$ & Atomizing Air & Blower Speed (\%) & Pump RPM & Spray g/min \\
\hline $15: 00$ & 68 & 40 & 41 & 1.1 & 28 & 2 & 2 \\
\hline $30: 00$ & 66 & 38 & 45 & 1.1 & 25 & 4 & 5 \\
\hline $45: 00$ & 64 & 34 & 46 & 1.3 & 23 & 5 & 6 \\
\hline $60: 00$ & 65 & 36 & 48 & 1.4 & 24 & 4 & 5 \\
\hline $1: 00$ & 63 & 36 & 45 & 1.6 & 25 & 5 & 6 \\
\hline $1: 15$ & 61 & 35 & 42 & 1.8 & 26 & 7 & 6 \\
\hline $1: 30$ & 60 & 34 & 40 & 2.0 & 28 & 6 & 7 \\
\hline $1: 45$ & 59 & 33 & 37 & 1.8 & 32 & 7 & 6 \\
\hline $2: 00$ & 57 & 31 & 39 & 1.8 & 33 & 5 & 7 \\
\hline $2: 15$ & 61 & 37 & 41 & 2.0 & 32 & 7 & 8 \\
\hline
\end{tabular}

Table 3b: Granulation Parameters

\begin{tabular}{|c|c|c|c|}
\hline Stage & Impeller & Chopper & Time \\
\hline Dry Mix & Slow & Off & 15 minutes \\
\hline Binder Solution Addition & Slow & Off & 2 minutes \\
\hline \multirow{3}{*}{ Kneading } & Slow & Slow & 1 minute \\
\cline { 2 - 4 } & Slow & Fast & 1 minute \\
\cline { 2 - 4 } & Fast & Fast & 2 minutes \\
\hline
\end{tabular}

Table 4: In Process Blend Result of Telmisartan

\begin{tabular}{|c|c|c|c|c|c|c|}
\hline Batch No & BD (g/ml) & T D (g/ml) & CI (\%) & Hausner's Ratio & Angle of Repose & LOD (\%) \\
\hline Trial 01 & - & - & - & - & - & - \\
\hline Trial 02 & - & - & - & - & - & - \\
\hline Trial 03 & - & - & - & - & - & - \\
\hline Trial 04 & 0.60 & 0.63 & 19 & 1.16 & 38 & 1.3 \\
\hline Trial 05 (A) & 0.56 & 0.61 & 16 & 1.14 & 36 & 1.4 \\
\hline Trial 05 (B) & 0.53 & 0.58 & 18 & 1.13 & 35 & 1.2 \\
\hline Trial 05 (C) & 0.48 & 0.54 & 15 & 1.17 & 32 & 0.9 \\
\hline Trial 06 (A) & 0.46 & 0.52 & 12 & 1.16 & 31 & 1.1 \\
\hline Trial 06 (B) & 0.45 & 0.48 & 14 & 1.15 & 33 & 1.3 \\
\hline Trial 06 (C) & 0.46 & 0.50 & 15 & 1.14 & 34 & 0.8 \\
\hline
\end{tabular}


Table 5: In Process Blend Result of Hydrochlorothiazide

\begin{tabular}{|c|c|c|c|c|c|c|}
\hline Batch No & BD (g/ml) & TD (g/ml) & CI (\%) & Hausner's Ratio & Angle of Repose & LOD (\%) \\
\hline Trial 04 & 0.63 & 0.69 & 18 & 1.17 & 39 & 1.3 \\
\hline Trial 05 (A) & 0.52 & 0.61 & 15 & 1.15 & 36 & 1.4 \\
\hline Trial 05 (B) & 0.52 & 0.61 & 15 & 1.15 & 36 & 1.4 \\
\hline Trial 05 (C) & 0.52 & 0.61 & 15 & 1.15 & 36 & 1.4 \\
\hline Trial 06 (A) & 0.48 & 0.57 & 12 & 1.16 & 33 & 1.2 \\
\hline Trial 06 (B) & 0.48 & 0.57 & 12 & 1.16 & 33 & 1.2 \\
\hline Trial 06 (C) & 0.48 & 0.57 & 12 & 1.16 & 33 & 1.2 \\
\hline
\end{tabular}

Table 6: In Process Tablet Results

\begin{tabular}{|c|c|c|c|c|}
\hline Batch No & Average weight (mg) & Thickness (mm) & Friability (\%) & Hardness (N) \\
\hline Trial 01 & - & - & - & - \\
\hline Trial 02 & - & - & - & - \\
\hline Trial 03 & - & - & - & - \\
\hline Trial 04 & 684 & $5.60-5.90$ & Nil & $135-155$ \\
\hline Trial 05 (A) & 682 & $5.90-6.10$ & Nil & $129-145$ \\
\hline Trial 05 (B) & 679 & $5.93-6.00$ & Nil & $134-154$ \\
\hline Trial 05 (C) & - & - & - & - \\
\hline Trial 06 (A) & 681 & $5.80-6.01$ & Nil & $132-155$ \\
\hline Trial 06 (B) & 682 & $5.85-5.98$ & Nil & $125-145$ \\
\hline Trial 06 (C) & 679 & $5.90-6.10$ & Nil & $127-150$ \\
\hline
\end{tabular}

Table 7: Compression Parameters and Observations

\begin{tabular}{|c|c|c|}
\hline S. No. & Compression Parameters & Observations \\
\hline 1 & Punch & $16.2 * 7.9 \mathrm{~mm}$ capsule shape \\
\hline 2 & Tablet weight (Average) & $684 \mathrm{mg}$ \\
\hline 3 & Hardness & $135-155 \mathrm{~N}$ \\
\hline 4 & Thickness & $5.6-5.9 \mathrm{~mm}$ \\
\hline 5 & \% Friability & Nil \\
\hline 6 & Disintegration Time & $11.0-13.0$ minutes \\
\hline 7 & \% Assay ( Telmisartan / HCTZ ) & $99.9 / 100.2$ \\
\hline
\end{tabular}

Table 8: Dissolution Specification

\begin{tabular}{|c|c|}
\hline Layer & Telmisartan \\
\hline Apparatus & USP Type 2, Speed 75 RPM \\
\hline Media and Volume & $\mathrm{pH} \mathrm{7.5} \mathrm{Phosphate} \mathrm{Buffer,} \mathrm{900} \mathrm{ml}$ \\
\hline
\end{tabular}

Table 9: Comparison of Dissolution Profile

\begin{tabular}{|c|c|c|c|c|c|c|c|}
\hline \multirow{2}{*}{$\begin{array}{c}\text { Time } \\
(\mathbf{m i n})\end{array}$} & \multicolumn{9}{|c|}{ \% w/w drug release } \\
\cline { 2 - 8 } & Innovator & $\mathbf{T - 0 4}$ & $\mathbf{T - 0 5}(\mathbf{A})$ & $\mathbf{T - 0 5}(\mathbf{B})$ & $\mathbf{T - 0 6}(\mathbf{A})$ & T-06 (B) & T-06 (C) \\
\hline 0 & 0 & 0 & 0 & 0 & 0 & 0 & 0 \\
\hline 5 & 41 & 20 & 22 & 55 & 40 & 48 & 51 \\
\hline 10 & 72 & 43 & 44 & 86 & 72 & 79 & 82 \\
\hline 15 & 92 & 61 & 62 & 93 & 90 & 92 & 98 \\
\hline 20 & 98 & 76 & 78 & 95 & 98 & 97 & 99 \\
\hline 30 & 100 & 93 & 95 & 98 & 100 & 99 & 100 \\
\hline 45 & 100 & 98 & 98 & 100 & 100 & 100 & 100 \\
\hline 60 & 100 & 98 & 98 & 100 & 100 & 100 & 100 \\
\hline F1 & - & $\mathbf{2 7}$ & $\mathbf{2 5}$ & $\mathbf{1 4}$ & $\mathbf{1}$ & $\mathbf{7}$ & $\mathbf{1 3}$ \\
\hline F2 & - & $\mathbf{3 1}$ & $\mathbf{3 3}$ & $\mathbf{4 7}$ & $\mathbf{8 9}$ & $\mathbf{6 2}$ & $\mathbf{5 2}$ \\
\hline
\end{tabular}

Table 10: Dissolution Specification

\begin{tabular}{|c|c|}
\hline Layer & Hydrochlorothiazide \\
\hline Apparatus & USP Type 2, Speed 75 RPM \\
\hline Media and Volume & $\mathrm{pH} \mathrm{7.5} \mathrm{Phosphate} \mathrm{Buffer,} \mathrm{900} \mathrm{ml}$ \\
\hline
\end{tabular}

Table 11: Comparison of Dissolution Profile

\begin{tabular}{|c|c|c|c|c|}
\hline Time (min) & Innovator & T- 04 & T- 05 (A) & T-06 (A) \\
\hline 0 & 0 & 0 & 0 & 0 \\
\hline 5 & 95 & 85 & 84 & 85 \\
\hline 10 & 97 & 96 & 95 & 96 \\
\hline 15 & 99 & 99 & 98 & 99 \\
\hline 20 & 99 & 100 & 100 & 100 \\
\hline 30 & 100 & 100 & 100 & 100 \\
\hline 45 & 100 & 100 & 100 & 100 \\
\hline 60 & 100 & 100 & 100 & 100 \\
\hline
\end{tabular}




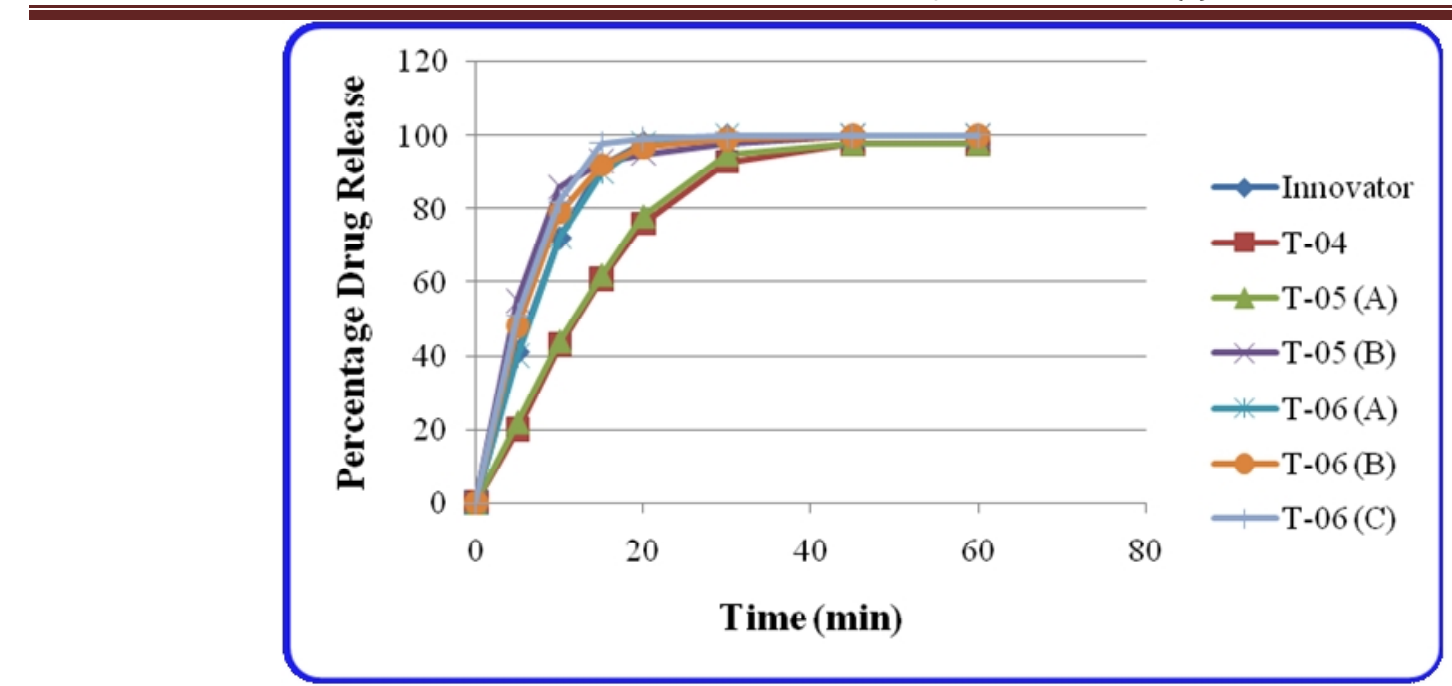

Figure 1: Comparison of Dissolution Profile of Innovator Vs Trial of Telmisertan

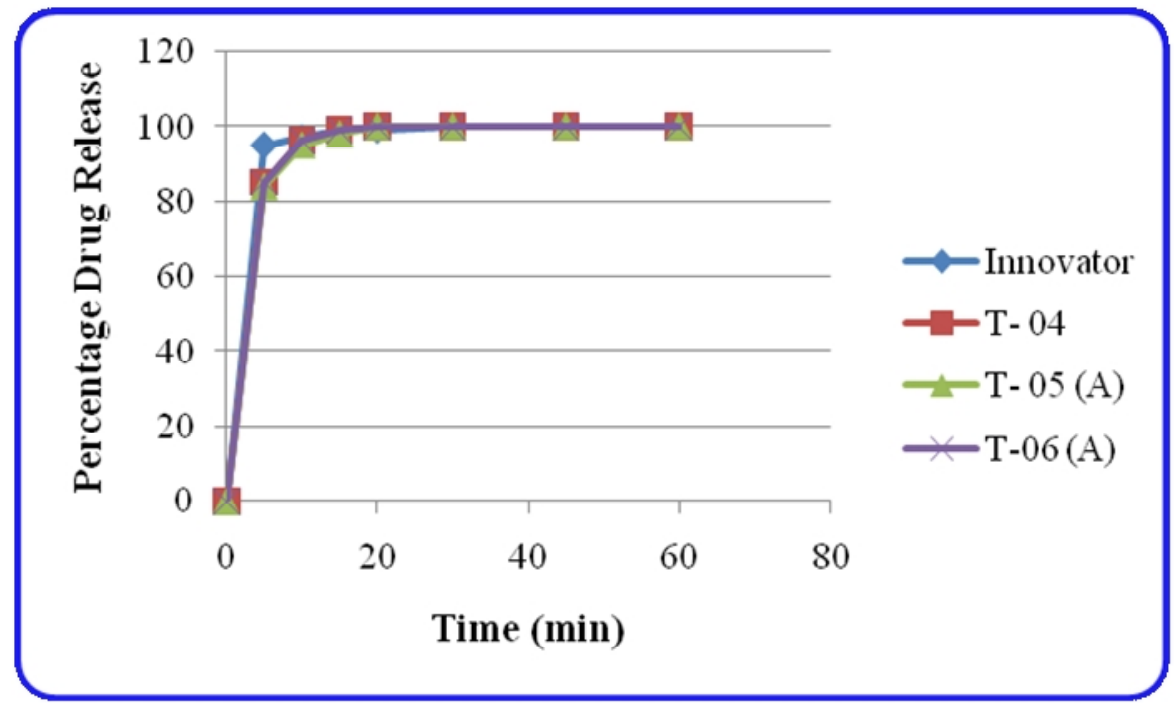

Figure 2: Comparison of Dissolution Profile of Innovator Vs Trial of HCTZ

Table 12: Stability Studies Batch 06 (A) Pack: Alu- Alu Blister Pack

\begin{tabular}{|c|c|c|c|}
\hline S. No. & Parameter & Initial & $\mathbf{1}$ Month Condition $\mathbf{4 0} \mathbf{C}^{\circ} \mathbf{C} \mathbf{7 5} \% \mathbf{R H}$ \\
\hline 1 & Tablet weight (Average) & $681 \mathrm{mg}$ & $682 \mathrm{mg}$ \\
\hline 2 & Hardness & $132-155 \mathrm{~N}$ & $135-154 \mathrm{~N}$ \\
\hline 3 & Thickness & $5.80-6.01 \mathrm{~mm}$ & $5.7-6.0 \mathrm{~mm}$ \\
\hline 4 & \% Friability & Nil & Nil \\
\hline 5 & Disintegration Time & $9.5-11.5$ minutes & 11 minutes \\
\hline 6 & \% Assay (Telmisartan/HCTZ) & $100.5 / 102.1$ & 101.9 \\
\hline
\end{tabular}

In Trial 06 (C) (Magnesium Stearate: Sodium Stearyl Fumarate is 75:25)

Compaction and compression parameters were satisfactory. The drug release profile of Telmisartan was very fast as compare to the innovator's drug release profile. The drug release profile of $\mathrm{HCTZ}$ was found to be satisfactory with the innovator's drug release profile in previous sub trial and in this trial common granules were used therefore we did not go for dissolution study of HCTZ. Dissolution profile of Trial 06 (A) was perfectly match with the innovator's product and also F2 value of that batch was 89 . Therefore, that batch was considered as optimized batch of formulation and 1 month stability study was done of batch 06 (A).
Stability Studies Batch 06 (A)

All parameters were as per specification after stability studies at Condition of $40^{\circ} \mathrm{C} / 75 \% \mathrm{RH}$. There was no significant change in dissolution profile of trial 06 (A) after stability studies and it was match with innovator's product. $\mathrm{F} 2$ value of trial 06 (A); before stability was 89 and after stability was 88.

\section{REFERENCES}

1. Atram SC. Formulation and evaluation of immediate release tablet using response surface methodology. Asian Journal of Pharmaceutics 2011; 5(1): 46-51. http://dx.doi.org/10.4103/0973-8398.80069

2. Barreras A, Turner CG. Angiotensin II receptor blockers. Baylor University Medical Center Proceedings 2003; 16: 123-126. PMid:162 78727 PMCid:PMC1200815

3. Brahmankar DM, Jaiswal SB. Bio pharmaceutics and Pharmacokinetics; A Treatise, $1^{\text {st }}$ Edition, Vallabh Prakashan; 1995. p. 347-352. 
4. Burnier M. Angiotensin II type I receptor blockers. Journal of the American Heart Association 2001; 103: 904-912.

5. Burnier M. Telmisartan, a different angiotensin II receptor blocker protecting a different population? The Journal of International Medical Research 2009; 37: 1662-1679. http://dx.doi.org/10.1177/147323000903 700602 PMid:20146864

6. Deshpande RD, Gowda DV, Mahammed N, Maramwar DN. Bilayer tablets- An emerging trend. International Journal of Pharmaceutical Sciences and Research 2011; 2(10): 2534-2544.

7. Gradman AH, Basile JN, Carter BL, Bakris GL. Combination therapy in hypertension. Journal of the American Society of Hypertension 2010; 4(2): 90-98. http://dx.doi.org/10.1016/j.jash.2010.03.001 PMid:20400 053

8. Gupta R. Trends in hypertension epidemiology in India. Journal of Human Hypertension 2004; 73-78. http://dx.doi.org/10.1038/sj.jhh.1 001633 PMid:14730320

9. Hemalatha T, Vasanth PM, Suresh K, Ramesh T, Molothu R. Formulation, optimization and evaluation of Telmisaratan Tablets. International Journal of Pharmacy and Therapeutics 2013; 4(1): 19-24.
10. Jain NK, Sharma SN. A Text Book of Professional Pharmacy. $4^{\text {th }}$ edition, Vallabh Prakashan; 2004. p. 289-298.

11. Keleb EI, Vermeire A, Vervaet C, Remon JP. Continuous twin screw extrusion for the wet granulation of lactose. International Journal of Pharmaceutics 2002; 239: 69-80. http://dx.doi.org/10.1016/S03785173(02)00052-2

12. Kottala N, Abebe A, Sprockela O, Akseli I, Nikfar F, Cuitino AM. Influence of compaction properties and interfacial topography on the performance of bilayer tablets. International Journal of Pharmaceutics 2012; 436: 171-178. http://dx.doi.org/10.1016/j.ijpharm.2012.05.026 PMid:22728259

13. Lieberman HA, Lachman L, Schwartz JB. Pharmaceutical Dosage Forms: tablets, $2^{\text {nd }}$ Edition; 2003. p. 212-227.

Cite this article as:

Bhavsar Bhavesh, Chauhan Manish, Biswal Biswajit. Formulation development and evaluation of immediate release bilayer tablets of Telmisertan and hydrochlorothiazide. Int. Res. J. Pharm. 2013; 4(9):117-122 http://dx.doi.org/10.7897/2230-8407.04925 